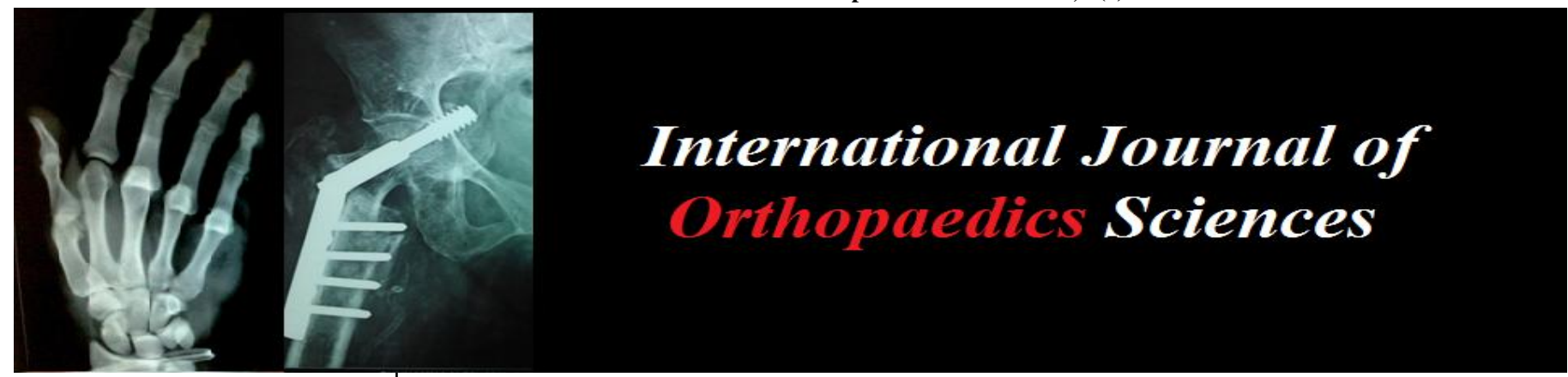

ISSN: $2395-1958$

IJOS 2017; 3(2): 30-31

(C) 2017 IJOS

www.orthopaper.com

Received: 08-02-2017

Accepted: 09-03-2017

Dr. Ashutosh Kumar

M.S. (Ortho.), Senior Resident Department of Orthopaedics,

IGIMS, Patna, India

Dr. Vidya Sagar

M.S. (Ortho.), Senior Resident,

Department of Orthopaedics,

IGIMS, Patna, India

Dr. Amarjeet Kumar

M.D, Senior Resident,

Department of Anesthesia,

AIIMS, Patna, India

Dr. Manish Ranjan

Assistant Professor,

Department of Orthopedic,

PMCH, Patna, India

\section{Bizarre parosteal osteochondromatous proliferation (Nora's lesion) of middle phalanx in an adult female}

\author{
Dr. Ashutosh Kumar, Dr. Vidya Sagar, Dr. Amarjeet Kumar and \\ Dr. Manish Ranjan
}

DOI: $\underline{\text { http://dx.doi.org/10.22271/ortho.2017.v3.i2a.08 }}$

\section{Abstract}

Bizarre parosteal osteochondromatous proliferation (BPOP; also called Nora's lesion) is a benign surface osteocartilaginous lesion. This condition seen in hands followed by the feet, long bones and the skull. The importance of the lesion lies in its clinical and pathological differentiation from malignant lesions mainly in osteosarcoma in children and chondrosarcoma in adults. The lesion is $20-50 \%$ recurrence rate. We present a case report of BPOP of the middle phalanx of the right middle finger. The importance of the case lies the involvement of phalanges is not rare, but if present it mainly in the proximal phalanges. In my case present in middle phalanx of the right middle finger.

Keywords: Bizarre parosteal osteochondromatous proliferation, middle phalanx, adult female

\section{Introduction \\ Case report}

A 35-year-old female presented to our outpatient clinic with pain and slowly progressive swelling on the radial aspect of middle phalanx of the right middle finger, with no apparent trigger. Swelling was present for the past 13 years but pain emerged only recently. Pain was unrelenting and not related to activity. Due to pain and cosmetic reason she requested a consultation. On physical examination a discrete, non mobile, hard mass measuring $2 \times 0.7 \mathrm{~cm}$ was fixed to the underlying bone with no overlying skin changes. There was minimal tenderness on deep palpation and minimal restriction on the terminal movement of distal interphalangeal joint. Neurovascular examination was normal. Plain X-rays showed a well circumscribed bone-like mass around the distal half of the middle phalanx of the middle finger on the right hand. There was neither breach in the cortex nor medullary involvement. Enbloc resection and decortications were done to prevent the reoccurrence of the bizarre parosteal osteochondromatous proliferation (BPOP). Under ultrasound guided median and radial nerve block was performed by the Anaesthesiologist using $0.5 \%$ bupivacaine of volume $3 \mathrm{ml}$ for each nerve before start of surgery. Gross specimen showed the surface of the lesion covered by a cartilage cap with osteoid tissue in the interior continuous with the cortical bone. Histopathological examination of specimen revealed cartilage at the margins of the lesion, bone at the center, with fibrous granulation tissue admixed in between. Diagnosis of BPOP was based on the preoperative imaging findings which were later confirmed by histopathological examination.

BPOP is a rare disease that typically presents as aparaosteal mass affecting the surface of bones in the hands and feet, especially the proximal and middle phalanges and carpals and tarsal bones ${ }^{[1]}$. It presents as an exophytic outgrowth consisting of cartilage, fibrous tissue and bone. Histologically it is characterized by a heterogeneous mixture of bone, cartilage, and fibrous tissue in the exophytic outgrowth ${ }^{[2]}$. Despite no malignant transformation, metastasis, or death associated with BPOP it has a very high rate of reoccurrence, $50 \%$ within 2 months to 2 years of surgery ${ }^{[3]}$. Despite having characteristic clinical, radiological and histological features, it is repeatedly confused with other benign and malignant lesions such as paraosteal osteosarcoma, and osteochondroma.

Resection of the capsule with decortication of the underlying cortical bone is the treatment of choice to reduce the reoccurrence rate ${ }^{[4]}$. Due to misdiagnosis and inappropriate treatment associated with BPOP the clinical, radiological and histological features should be considered to make a correct diagnosis as many conditions may mimic BPOP.
Dr. Ashutosh Kumar

M.S. (Ortho.), Senior Resident Department of Orthopaedics,

IGIMS, Patna, India 


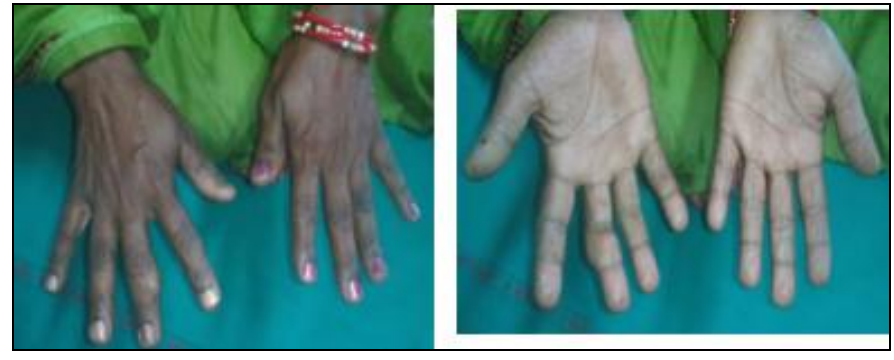

Fig 1: Nora's lesion Right middle Finger

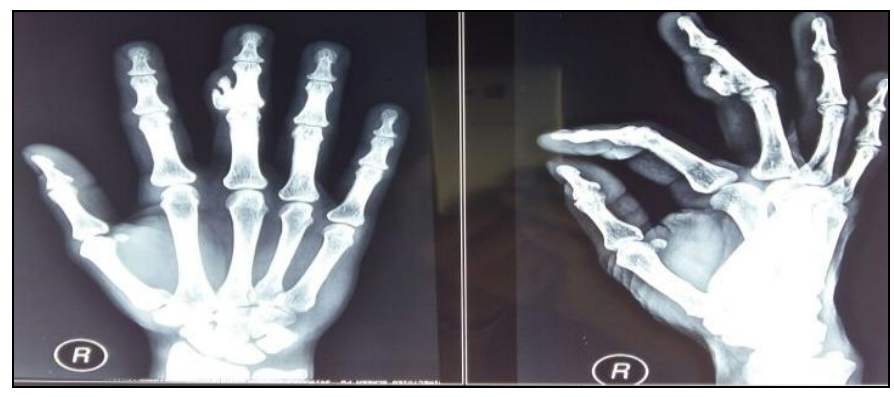

Fig 2: X-ray of Nora's lesion Middle Phalanx of Right middle Finger

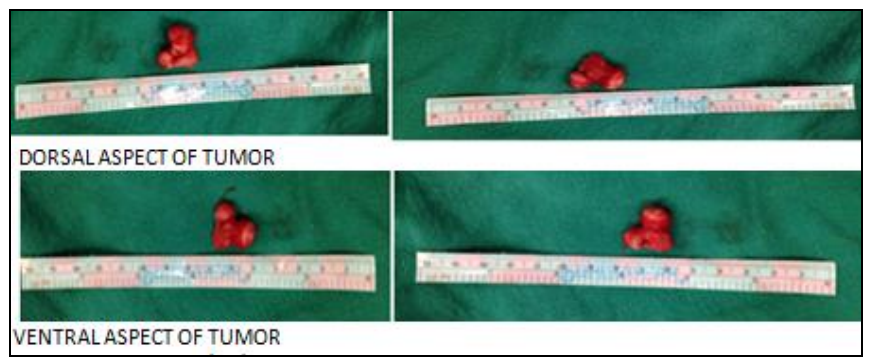

Fig 3: Intraoperative measurement of tumor size

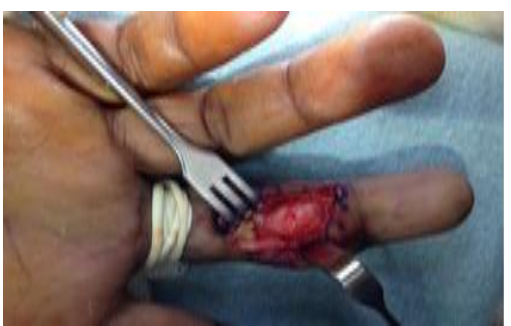

Exposure of tumor through dorsal incision and under figure turniqute

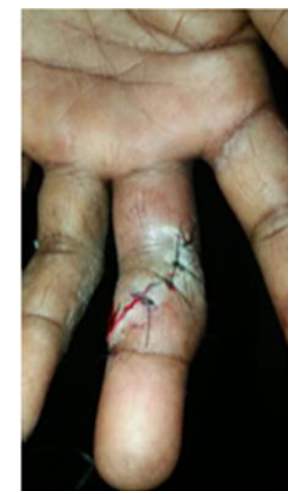

$2^{\text {nd }}$ Post operative of wood

Fig 4: Exposure of wound through dorsal inscion

\section{Differential diagnosis}

Osteochondoma

BPOP

Turret exostosis

Florid reactive periostitis

Juxtaphyseal osteosarcoma

\section{Discussion}

BPOP was first described by Nora and colleagues. They reported 35 cases of what they described as 'peripheral skeletal osteochondromatous tumefactions', which were histologically and radiologically distinctive. It is a benign lesion with atypical microscopic features and a high chance of recur. Hands are the commonest site of involvement followed by the feet and skull. The importance of the case lies the involvement of phalanges is not rare, but if present it mainly in the proximal phalanges. In my case present in middle phalanx of the right middle finger.

In summary, BPOP is a rare osteocartilaginous lesion, mainly occure in the adult population. In view of a varied differential diagnosis and a high rate of local recurrence, an early identification and a wide excision are essential in Nora's lesions. Bizarre parosteal osteochondromatous proliferation (Nora's lesion) can occur in middle phalanx. The condition needs to be differentiated from florid reactive periostitis, turret exostosis, osteochondroma and juxtaphyseal osteosarcoma.

\section{References}

1. Soubeyrand M, De Pinieu G, Biau D. Bizarre parosteal osteochondromatous proliferation (Nora's lesion): two cases Rev Chir Orthopédique Mot 2007; 93:494.

2. Meneses MF, Unni KK, Swee RG. Bizarre parosteal osteochondromatous proliferation of bone (Nora's lesion). Am J Surg Pathol. 1993; 17:691-7.

3. Berber O, Dawson-Bowling S, Jalgaonkar A. Bizarre parosteal osteochondromatous proliferation of bone clinical management of a series of 22 cases, J Bone Joint Surg. Br. 2011; 93:1118-21.

4. Nora FE, Dahlin DC, Beabout JW. Bizarre parosteal osteochondromatous proliferations of the hands and feet, Am J Surg. Pathol. 1983; 7:245-50.

5. Gruber G, Giessauf C, Leithner A. Bizarre parosteal osteochondromatous proliferation (Nora lesion): a report of 3 cases and a review of the literature Can J Surg. 2008; 51:486.

6. Kraft D, Hailer NP. [Nora's lesion at the second metacarpal bone of a twelve-year-old female], $\mathrm{Z}$ Für Orthop Ihre Grenzgeb 2006; 144:228.

7. Miyajima T, Sakada T, Azuma H. Bizarre parosteal osteochondromatous proliferation in a child's hand, $\mathbf{J}$ Hand Surg. Br Eur. 1997; 22:472-3.

8. Suresh SS. Nora's lesion of the second toe, Indian $\mathbf{J}$ Orthop. 2010; 44:342.

9. Horiguchi H, Sakane M, Matsui M. Bizarre parosteal osteochondromatous proliferation (Nora's lesion) of the foot Pathol. Int 2001; 51:816-23.

10. Nilsson M, Domanski HA, Mertens F. Molecular cytogenetic characterization of recurrent translocation breakpoints in bizarre parosteal osteochondromatous proliferation (Nora's lesion). Hum Pathol 2004; 35:1063-9.

11. Cañueto J, Santos-Briz Á, Yuste-Chaves M. Exostosis de Turret: osteocondroma adquirido Actas DermoSifiliográficas 2011; 102:474-5.

12. Michael Yuen MB, William Orr MD. Proliferative periosteal processes of phalanges: a unitary hypothesis. Skeletal Radiol 1992; 21:301-3.

13. Davies CT. Bizarre parosteal osteochondromatous proliferation in the hand: a case report, J Bone Joint Surg. Am 1985; 67:648-50.

14. Michelsen H, Abramovici L, Steiner G. Bizarre parosteal osteochondromatous proliferation (Nora's lesion) in the hand, J Hand Surg. 2004; 29:520-5. 